\title{
Thermophysical Properties and Supercritical Heat Transfer Characteristics of R515A
}

\author{
Adnan Ibrahim1, Peng Hu1, Yiran Jiang'1, Farrukh Saleem², Ali Riaz ${ }^{3}$, Yifang Dong², Lei Jia4, \\ Panpan Zhao ${ }^{4}$
}

${ }^{1}$ Department of Thermal Science and Energy Engineering, University of Science and Technology of China, Hefei, China; ${ }^{2}$ School of Engineering Science, University of Science and Technology of China, Hefei, China; ${ }^{3}$ Department of Mechanical Engineering, Pakistan Institute of Engineering and Applied Sciences, Islamabad, Pakistan; ${ }^{4}$ Hefei General Machinery Research Institute Co., Ltd., Hefei, China

Correspondence to: Peng Hu, hupeng@ustc.edu.cn; Lei Jia, magic9613@126.com

Keywords: Environmental Friendly Refrigerant, Supercritical Fluid R515A, Simulations, Heat Transfer Correlations, Shear-Stress Transport (SST) Model

Received: May 9, $2021 \quad$ Accepted: June 20, $2021 \quad$ Published: June 23, 2021

Copyright $\odot 2021$ by author(s) and Scientific Research Publishing Inc.

This work is licensed under the Creative Commons Attribution-NonCommercial International License (CC BY-NC 4.0).

http://creativecommons.org/licenses/by-nc/4.0/

(c) (i) (8) Open Access

\section{ABSTRACT}

The heat transfer of supercritical fluids is a vastly growing field, specifically to find suitable alternative to replace conventional R134a, which can be beneficial for climate change. A considerable suggestion is R515A which possesses considerably lower global warming potential. The present simulations are designed to study supercritical fluid R515A under cooling conditions in horizontal position. The effect of pressure, mass flux, heat flux and tube diameter were considered for horizontal tube in the vicinity of pseudo critical temperature. Numerical investigations on heat transfer characteristics of supercritical fluid R515A were performed using widely used shear-stress transport (SST) model. Moreover, heat transfer correlations were developed and suggested to accurately predict Nusselt number within $10 \%$ accuracy. The simulation results showed about $3.98 \%$ average absolute deviation.

\section{INTRODUCTION}

Supercritical fluids have wide range of industrial applications owing to the substantial impact of their heat transfer characteristics [1-8]. Supercritical fluids, in comparison with conventional fluids, have attracted growing amount of attention because of relatively higher heat transfer rate and lower energy losses [9]. The thermophysical properties of supercritical fluids considerably vary near the critical $\left(T_{c}\right)$ or pseudo critical temperature $\left(T_{p c}\right)$. The heat transfer coefficient, owing to dramatic variations near pseudo-critical point, depends upon pressure, tube diameter, flow direction, heat flux and type of working fluid [10]. Therefore, this results in complex heat transfer characteristics which may account for heat transfer en- 
hancement or deterioration [11].

Most of the experimental and numerical investigations have been conducted to explore supercritical water and carbon dioxide $\left(\mathrm{sCO}_{2}\right)$ [12-18]. Dang and Hihara $[19,20]$ investigated the effects of tube diameter on heat transfer coefficient of $\mathrm{sCO}_{2}$ under cooling conditions and proposed the modified Gnielinski equation. Zhang and $\mathrm{Hu}$ [2] measured the effects of buoyancy and tube diameter for $\mathrm{sCO}_{2}$. The influence of mass flux, pressure and tube diameter were plotted against heat transfer coefficient and pressure drop. Further to that, dimensionless diameter was incorporated in the development of correlation which can precisely estimate heat transfer in large-diameter tube. Wang and Guan [21] computationally investigated underlying mechanism of buoyancy effects for supercritical carbon dioxide flowing through large horizontal tube. At higher heat flux, the buoyancy is more pronounced and can cause considerable difference in the temperature at top and bottom walls. Zahlan and Groeneveld [22] performed extensive experimental tests for $\mathrm{sCO}_{2}$ under vertical conditions.

However, supercritical organic fluids have not been thoroughly investigated for in tube heat transfer. Zhao and Jiang [23] examined that fluid temperature, mass flux and pressure can considerably impact the in-tube cooling heat transfer and flow of supercritical fluid R134a. Experimental data predicated (using the least square curve-fitting method) a modified Gnielinski's correlation which can give heat transfer coefficient within $\pm 15 \%$ accuracy. Wang and Tian [24] conducted experimental investigations for supercritical fluid R134a flowing through micro-fin and smooth tube under horizontal position. These measurements under different mass fluxes, heat fluxes and pressures suggested that micro-fin tube resulted in higher heat transfer coefficient than that of smooth tube. Herein, buoyancy criteria of $\frac{G r_{b}}{\operatorname{Re}_{b}^{2}}\left(\frac{\rho_{b}}{\rho_{w}}\right) \frac{x}{d}$ was suggested to accurately predict results. Further to that, micro-fin tube can significantly reduce the buoyancy effects. In more recent work, Wang and Tian [25] suggested that internally ribbed tube resulted in higher heat transfer coefficient than that of smooth tube under similar working conditions.

Kang and Chang [26] performed experiments for steady-state and transient-pressure in upward flow of supercritical fluid R134a. The study suggested that pressure transient rates have slight impact upon heat transfer rate. Cui and Wang [27] experimentally examined supercritical fluid R134a for different flow directions in a vertical tube. The data suggested good heat transfer in downward flow as compared to upward direction. He and Dang $[28,29]$ experimentally investigated supercritical fluid R245fa in vertical tube under heating condition. The experimental results revealed $70 \%$ data can be calculated by Yamagata's correlation within $\pm 30 \%$ accuracy. The experimental data of supercritical fluid R1233zd (E) showed good agreement with Petukhov's correlation. In comparison with supercritical fluid R245fa, supercritical fluid $\mathrm{R} 1233 z d(E)$ can bring higher heat transfer coefficient. Jiang et al. [30] compared supercritical fluid R-22 and ethanol using smaller tube $(1.004 \mathrm{~mm})$ under higher heat flux $\left(110-1800 \mathrm{~kW} \cdot \mathrm{m}^{-2}\right)$. Ethanol was suggested for better flow and heat transfer performance; therefore, it's reasonable for cooling applications in combustion chambers.

Xiong and $\mathrm{Gu}$ [31] performed experiments and numerical simulations to evaluate the intermittent heating effects for supercritical fluid R134a. After analyzing experimental data and simulation models, SST $\mathrm{k}-\omega$ model was suggested to accurately predict heat transfer enhancement as well as heat transfer deterioration. The decrease in velocity for near-wall region can cause heat transfer deterioration. Liu and Xu [32] compared nine turbulence models with experimental results of $\mathrm{sCO}_{2}$ passing through helical tube and suggested the Shear Stress Transport model for best prediction to heat transfer characteristics. The comparisons of various turbulent models were performed in previous research works for different supercritical fluids including $\mathrm{sCO}_{2}$ [32-36], supercritical water [37-42], supercritical methane [43], supercritical nitrogen [44], supercritical fluid R134a [31, 45, 46] and supercritical fluid R1234ze (E) [1]. These findings suggested good agreement between simulations (performed by SST k- $\omega$ model) and experimental data. This model can provide most accurate prediction to heat transfer coefficient, wall and bulk temperatures [36]; therefore, the present simulations of supercritical fluid R515A were performed using SST k- $\omega$ model.

$\mathrm{R} 515 \mathrm{~A}$ is non-flammable and azeotrope replacement of R134a [47], and the mixture information is 
shown in Table 1. It has a lower global warming potential (GWP) of 403 than that of R134a (1300 GWP of R134a). R515A/R1234yf system was suggested to lower emissions and increase energy efficiency as compared to R744 system [48].

In the previous research [1], supercritical fluid R1234ze (E) was thoroughly investigated to describe the heat transfer characteristics near pseudo-critical point. The correlations were divided into two regions (above and below pseudo-critical point) which can increase prediction accuracy. This work is continued for supercritical fluid R515A and it is a step forward to study and explore the environment-friendly refrigerants. The simulations performed in this study can provide details about heat transfer of supercritical fluid R515A under different mass fluxes, pressures and tube diameters. The heat transfer correlations were also developed on the basis of simulation results.

\section{NUMERICAL SIMULATIONS}

\subsection{Physical Model}

Thermophysical properties of supercritical fluid R515A vary considerably near pseudo-critical point, as shown in Figure 1. Therefore, it is crucial to investigate the supercritical heat transfer in the vicinity of $T_{p c}$ under different pressure rates. A 3D physical model is employed in the simulations to consider the effects of buoyancy for supercritical fluid R515A, as shown in Figure 2. Most of the commercial heat exchangers, which are employing organic Rankine cycle, are using horizontal flow direction rather than vertical $[1,2,25]$. Therefore, the present simulations adopted horizontal flow to explore the heat transfer. An adiabatic section $(200 \mathrm{~mm})$ is considered to eliminate the entrance effect, and constant heat flux boundary $(q)$ is used for the wall $(1000 \mathrm{~mm})$ with different diameters.

\subsection{Mathematical Model}

The detailed mathematical model is described below [35].

The continuity equation is described as:

$$
\frac{\partial}{\partial x_{i}}\left(\rho u_{i}\right)=0
$$

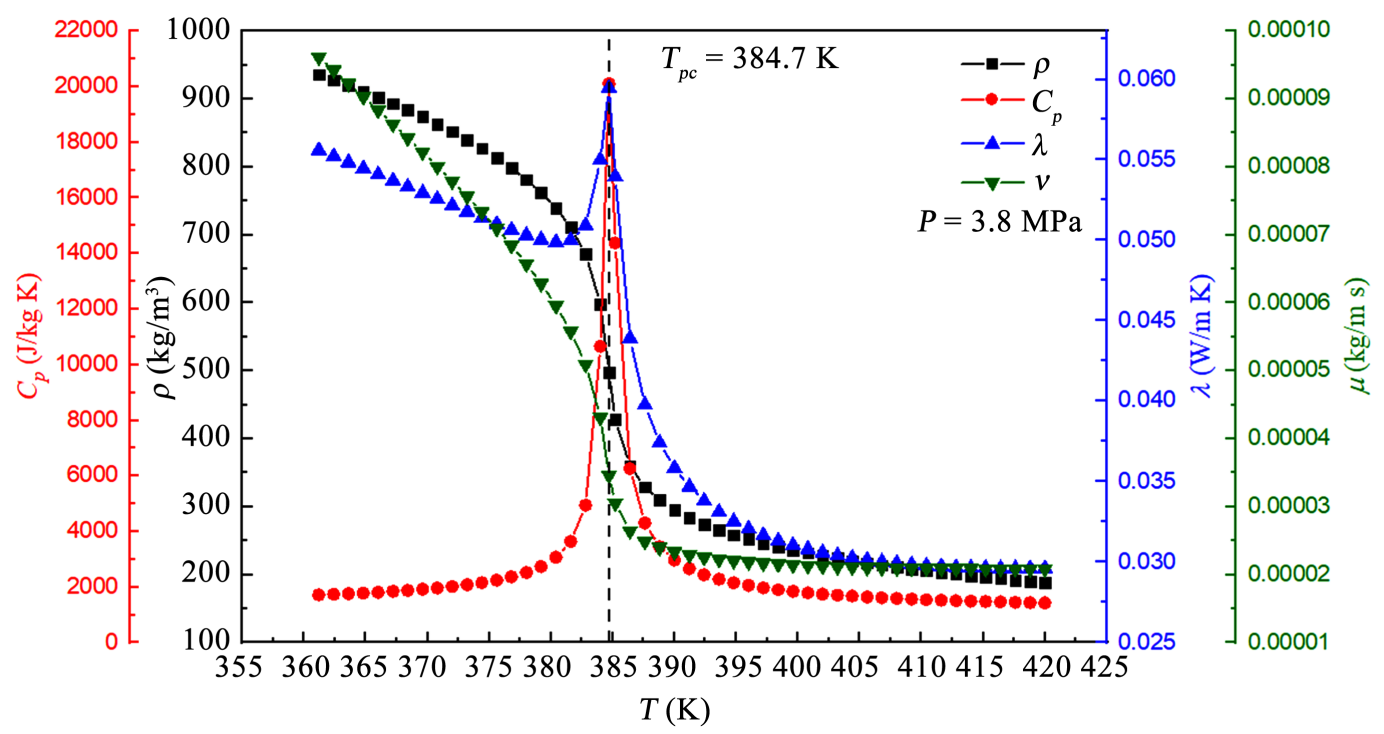

Figure 1. Supercritical fluid R515A at 3.8 MPa pressure showing variation in the values of density, specific heat, thermal conductivity and viscosity (REFPROP 9.1). 


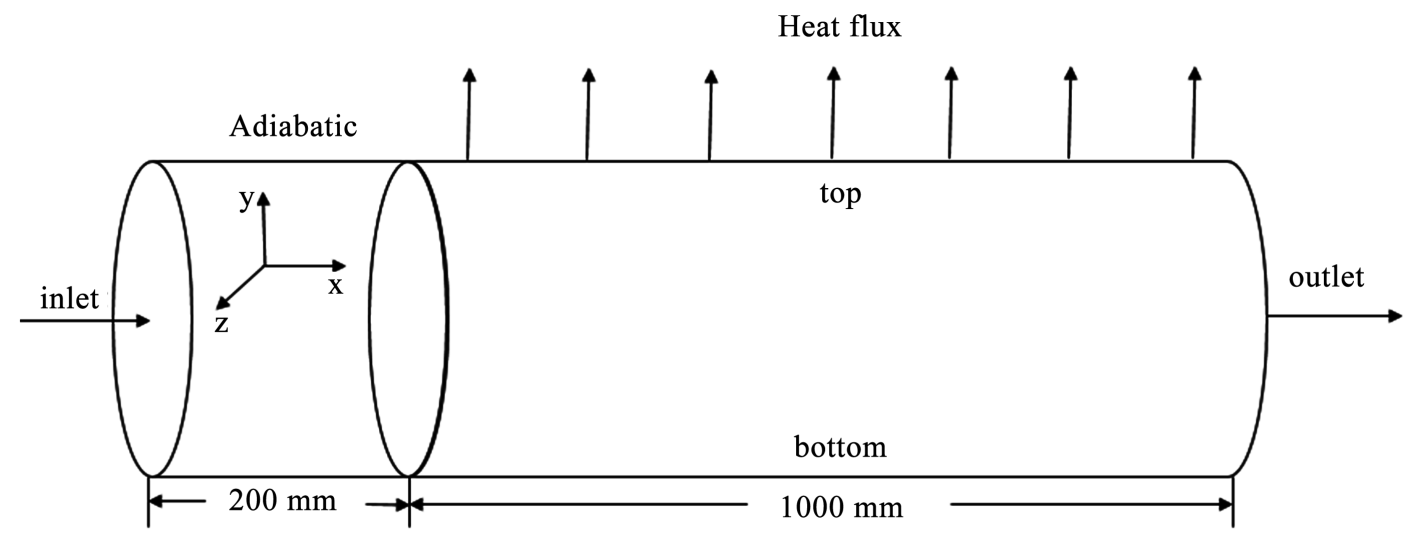

Figure 2. 3D physical model.

Table 1. Mixture information of R515A.

\begin{tabular}{cccc}
\hline Refrigerant & R1234ze [1] & R227ea [49] & R515A [50, 51] \\
\hline Composition & R1234ze & R227ea & R227ea/R1234ze \\
Mass percentage & 100 & 100 & $12 / 88$ \\
Critical pressure (MPa) & 3.6349 & 2.925 & 3.5581 \\
Critical temperature (K) & 382.51 & 374.9 & 381.31 \\
ODP & 0 & 0 & 0 \\
GWP & $<10$ & 3500 & 387 \\
\hline
\end{tabular}

The momentum equation is described as:

$$
\frac{\partial}{\partial x_{j}}\left(\rho u_{i} u_{j}\right)=\frac{\partial}{\partial x_{j}}\left[\mu_{e f f}\left(\frac{\partial u_{i}}{\partial x_{j}}+\frac{\partial u_{j}}{\partial x_{i}}\right)-\frac{2}{3} \mu_{e f f} \frac{\partial u_{k}}{\partial x_{k}}\right]-\frac{\partial p}{\partial x_{j}}+\rho g_{i}
$$

The energy equation is described as:

$$
\frac{\partial}{\partial x_{i}}\left(\rho u_{i} c_{p} T\right)=\frac{\partial}{\partial x_{i}}\left(\lambda \frac{\partial T}{\partial x_{i}}\right)+\Phi
$$

where $\mu_{\text {eff }}$ describes effective viscosity coefficient, and $\Phi$ describes energy dissipation.

The turbulent kinetic energy equation is described as [1,35]:

$$
\frac{\partial}{\partial t}(\rho k)+\frac{\partial}{\partial x_{i}}\left(\rho k u_{i}\right)=\frac{\partial}{\partial x_{j}}\left(\Gamma_{k} \frac{\partial k}{\partial x_{j}}\right)+G_{k}-Y_{k}+S_{k}
$$

The dissipation rate equation is described as:

$$
\frac{\partial}{\partial t}(\rho \omega)+\frac{\partial}{\partial x_{i}}\left(\rho \omega u_{i}\right)=\frac{\partial}{\partial x_{j}}\left(\Gamma_{\omega} \frac{\partial \omega}{\partial x_{j}}\right)+G_{\omega}-Y_{\omega}+D_{\omega}+S_{\omega}
$$

where $G_{k}$ and $G_{\omega}$ denotes the generation of $k$ and $\omega, \Gamma_{k}$ and $\Gamma_{\omega}$ denotes the effective diffusivity of $k$ and $\omega$, respectively, $Y_{k}$ and $Y_{\omega}$ denotes the dissipation of $k$ and $\omega$ due to turbulence, $D_{\omega}$ defines the cross-diffusion term, $S_{k}$ and $S_{\omega}$ are user-defined source terms. 


\subsection{Boundary Conditions}

ANSYS FLUENT was employed for 3D simulation of turbulent flow. The thermophysical properties of supercritical fluid R515A at different temperatures were taken from REFPROP 9.1 and input by piecewise-linear function. SST model was adopted for present simulations owing to relatively accurate results for a range of supercritical fluids. This model has been widely used for predicting reliable results. The detailed working conditions are described in Table 2 . The reference values including inlet velocity are computed from inlet for each case using ANSYS FLUENT. The following boundary conditions were adopted: mass flow inlet, outflow boundary, and constant wall heat flux. SIMPLE algorithm is used for pressure and velocity coupling.

The bulk temperature and heat transfer coefficient were calculated as follows:

$$
\begin{gathered}
T_{b}=\int_{0}^{A} \rho u T \mathrm{~d} A / \int_{0}^{A} \rho u \mathrm{~d} A \\
h=\frac{q}{T_{b}-T_{w}}
\end{gathered}
$$

where $T_{b}$ is the bulk temperature, $T_{W}$ is the wall temperature, $u$ is the local velocity and $A$ is the cross-sectional area of the tube.

\subsection{Mesh Independence Verification and Model Validation}

ANSYS ICEM is used to generate high-quality hexahedral mesh as shown in Figure 3. Keeping all the working conditions same, $h$ is plotted for different mesh sizes as illustrated in Figure 4 . The deviation in $h$ values obtained from different mesh sizes is trivial and further details have been described in Table 3. A reasonable compromise is to use mesh 2 for further simulations which can bring satisfactory accuracy and calculation speed.

The model verification is performed against experimental data presented by Dang and Hihara [19] and Jiang and $\mathrm{Hu}$ [1]. The present simulations resulted in a reliable heat transfer performance and better consistency with the experimental results (Figure 5) and can be employed for supercritical fluid R515A.

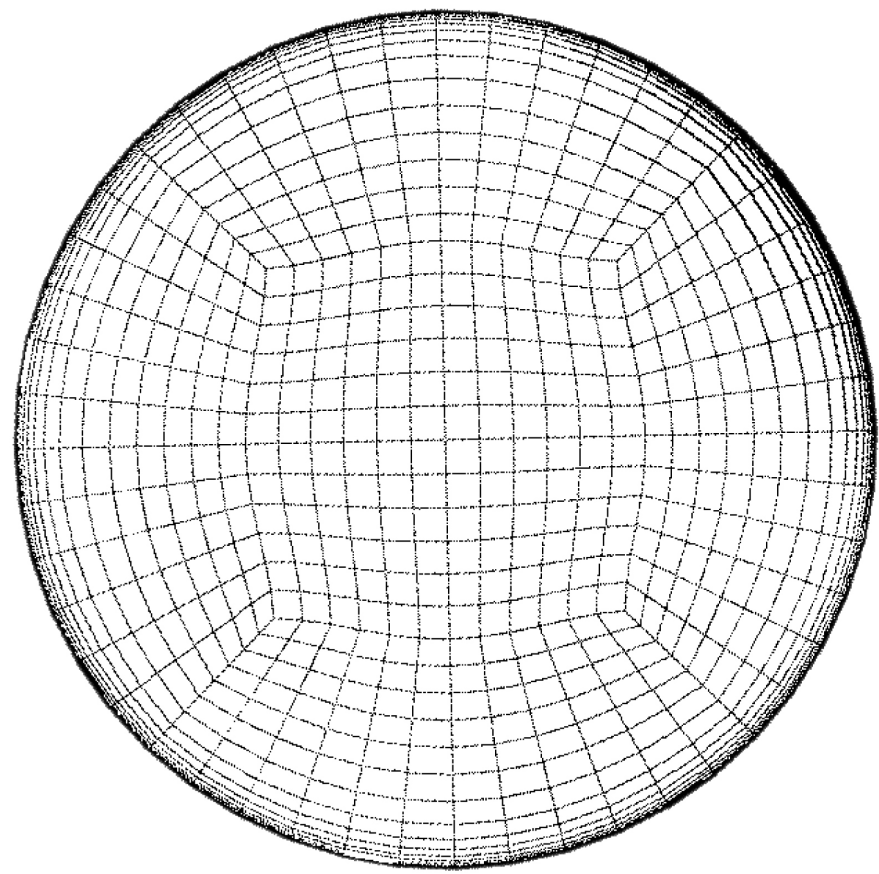

Figure 3. Details of mesh. 


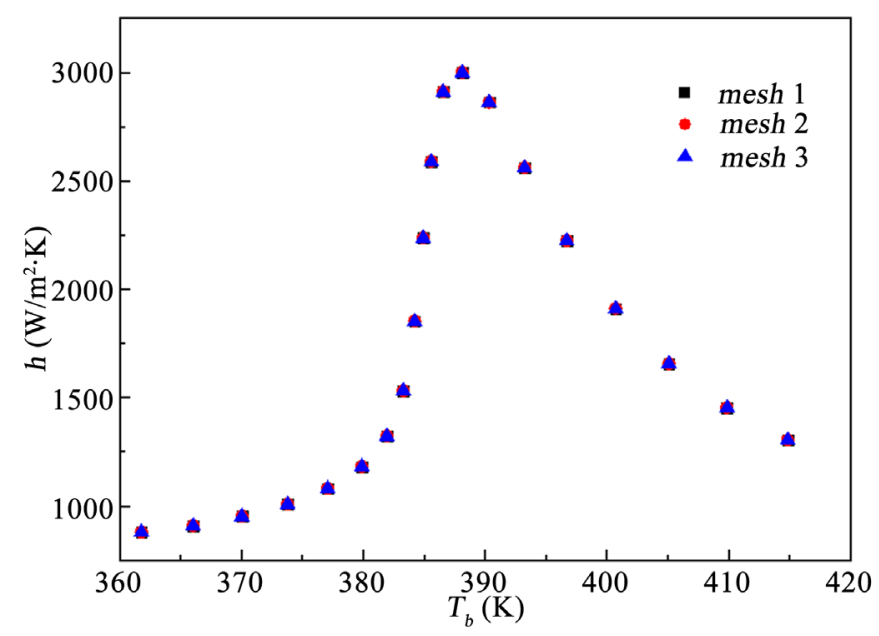

Figure 4. Mesh independence for different cell numbers.

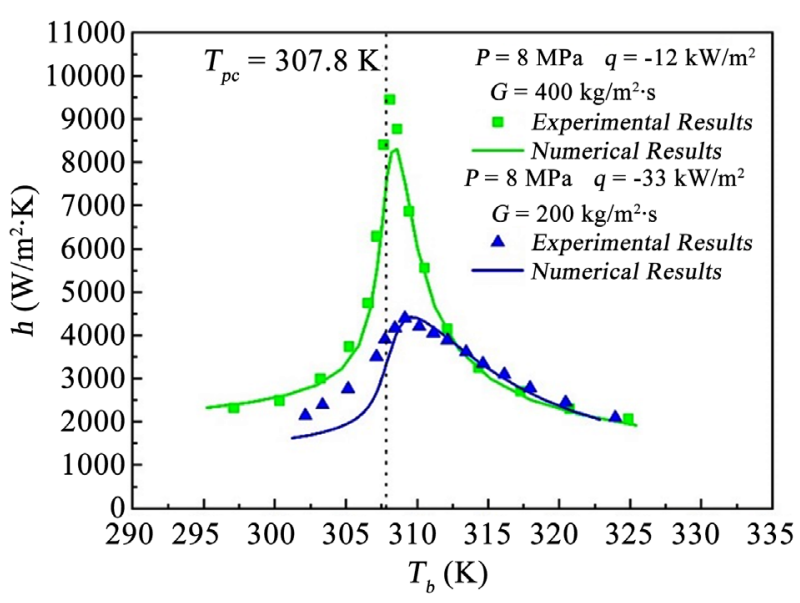

(a)

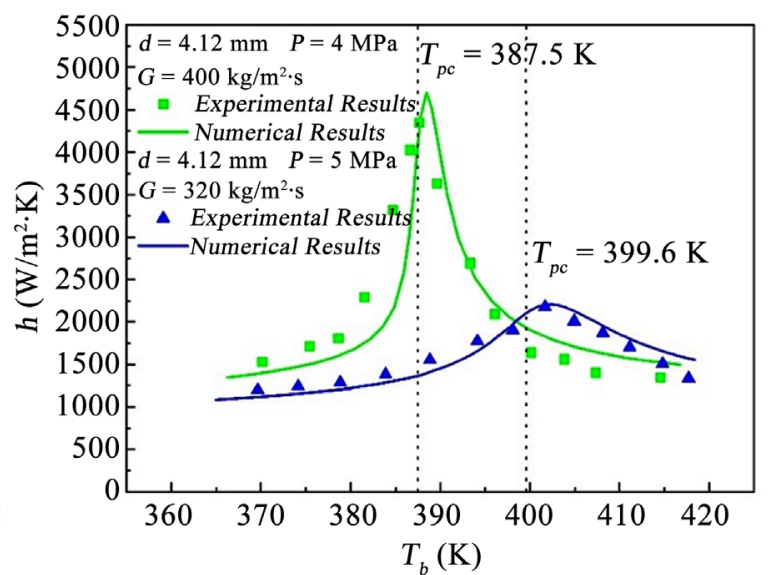

(b)

Figure 5. Model validation by comparing previous experimental data (a) Dang and Hihara [19] and (b) Jiang and $\mathrm{Hu}[1]$.

Table 2. Working conditions considered for CFD simulations.

\begin{tabular}{cccccc}
\hline case & $d(\mathrm{~mm})$ & $L(\mathrm{~mm})$ & $P(\mathrm{MPa})$ & $G\left(\mathrm{~kg} / \mathrm{m}^{2} \mathrm{~s}\right)$ & $q\left(\mathrm{~kW} / \mathrm{m}^{2}\right)$ \\
\hline 1 & 4.12 & 1000 & 3.8 & 240 & $-5,-10,-15$ \\
2 & 4.12 & 1000 & 3.8 & 320 & -10 \\
3 & 4.12 & 1000 & 3.8 & 400 & -10 \\
4 & 4.12 & 1000 & 4.3 & 320 & -10 \\
5 & 4.12 & 1000 & 4.8 & 320 & -10 \\
6 & 5.95 & 1000 & 3.8 & 240 & -10 \\
7 & 7.64 & 1000 & 3.8 & 240 & -10 \\
8 & 9.44 & 1000 & 3.8 & 240 & -10 \\
\hline
\end{tabular}


Table 3. Mesh independence for different cell numbers.

\begin{tabular}{ccc}
\hline mesh & Cell number & $h$ \\
\hline mesh 1 & $2,467,584$ & $0 \%$ \\
mesh 2 & $1,862,784$ & $0.02 \%$ \\
mesh 3 & $1,257,984$ & $0.06 \%$ \\
\hline
\end{tabular}

\section{RESULTS}

\subsection{Effect of Mass Flux}

Herein, the effects of mass flux on $h$ were considered by keeping other conditions the same. The increase in mass flux corresponded to an increase in $R e$ value (Figure 9) which resulted in a higher $h$ value (Figure 6) and this behavior is in agreement with Gnielinski equation. At $T_{b}=385.8 \mathrm{~K}$, slightly higher than $T_{p o}$ the heat transfer coefficient increased from $3242.4 \mathrm{~W} /\left(\mathrm{m}^{2} \cdot \mathrm{K}\right)$ to $5139.9 \mathrm{~W} /\left(\mathrm{m}^{2} \cdot \mathrm{K}\right)$ by increasing mass flux from $240 \mathrm{~kg} /\left(\mathrm{m}^{2} \cdot \mathrm{s}\right)$ to $400 \mathrm{~kg} /\left(\mathrm{m}^{2} \cdot \mathrm{s}\right)$, respectively. The peak values of $h$ occur near $T_{p c}=384.7 \mathrm{~K}$ for all the three cases with different mass fluxes. The influence of $G$ is considerably prominent around $T_{p c}$, specifically when the $T_{b}$ is slightly higher than $T_{p c}$. Higher values of $G$ resulted in increased $R e$ with thin boundary layer, consequently, increase in heat transfer and higher $h$ values as demonstrated in Figure 6.

The considered range of heat flux in the present simulations showed slight impact upon $h$ (Figure 7). When $T_{b} \geq T_{p c}$, heat transfer coefficient changes slightly with heat flux, however, when $T_{b}<T_{p c}$, the $h$ values remained almost unchanged with different $q$ values. The rest of the simulations were performed under heat flux of $10 \mathrm{~kW} / \mathrm{m}^{2}$. The turbulent kinetic energy distribution was demonstrated in Figure 8 at bulk temperature of $390 \mathrm{~K}$. Meanwhile, the bulk mean Reynolds numbers are plotted in Figure 9. The higher value of mass flux can considerably increase both the $k$ and $R e$ which correspond to the enhancement of heat transfer and higher $h$ values.

\subsection{Effect of Pressure}

Higher pressure may bring a decrement in heat transfer coefficient, meanwhile, the peak values move towards right, as demonstrated in Figure 10. There is considerable change in thermo-physical properties, specifically the sudden change in $c_{p}$ when pressure is in the vicinity of $T_{p c}$ as illustrated in Figure 1 . Herein, specific heat plays crucial role in the heat transfer of supercritical fluid R515A cooled in horizontal tubes. For different pressure values at $T_{b}<T_{p c}, h$ values are decreasing with increasing pressure. However, totally opposite trend was noticeable at $T_{b} \geq T_{p c}$ because of existing differences in thermo-physical properties and $T_{p c}$ for various pressure values. At lower temperature $\left(T_{b}<T_{p c}\right)$, there is a trivial change in the values of $h$ at different pressures; however, the higher temperature $\left(T_{b} \geq T_{p c}\right)$ may result in a noticeable change in $h$. Further increasing the temperature can result in a little effect of $T_{b}$ on $h$ values.

\subsection{Effect of Tube Diameter and Gravity}

Tube geometry, concerning different diameter, was considered for further simulations. The heat transfer coefficient may slightly lower with relatively large dimeter tube as demonstrated in Figure 11. The temperature contours at different tube diameters are shown in Table 4. The non-uniformity of temperature distributions was higher at large diameter tube, and the working fluid is inclined at upper regions owing to buoyancy effects.

The gravitational buoyancy showed trivial impact on heat transfer for the considered tube diameter (4.12 - $9.44 \mathrm{~mm}$ ), as manifested in Figure 12. The influence of buoyancy is related to Richardson number:

$$
R i_{g}=\frac{\left(\rho_{w}-\rho_{b}\right) \rho_{b} g d^{3}}{\mu_{b}^{2} R e_{b}^{2}}
$$




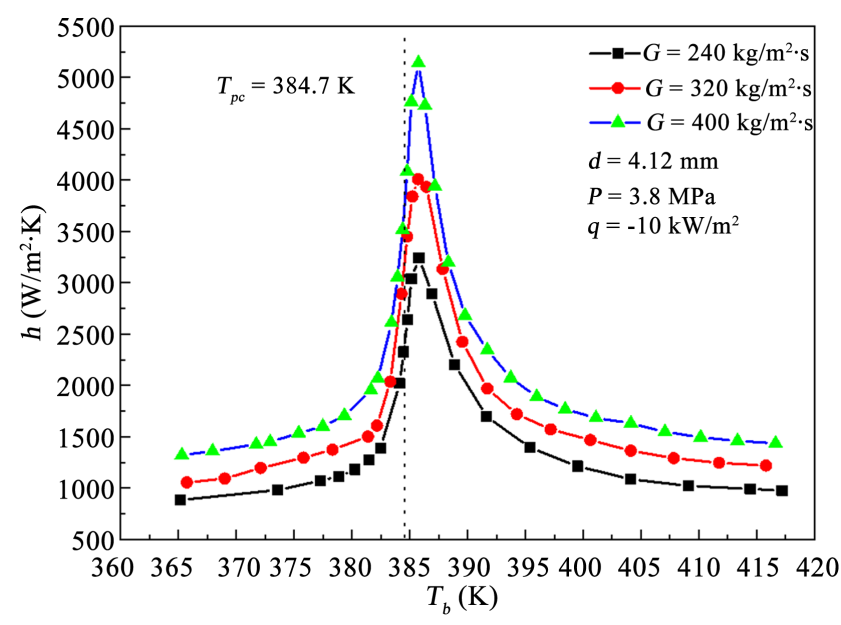

Figure 6. Effect of different mass fluxes on $h$ values.

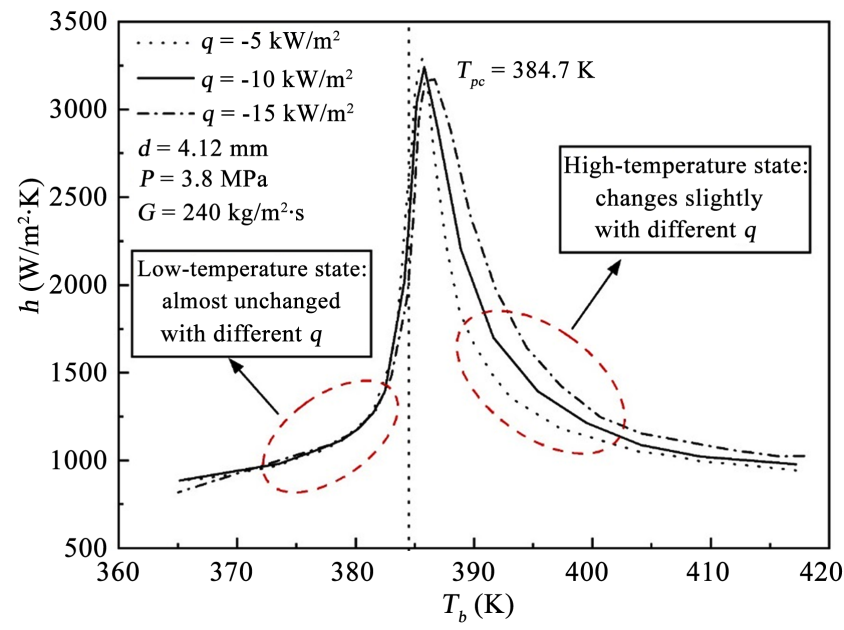

Figure 7. Effect of different heat flux on $h$ values.

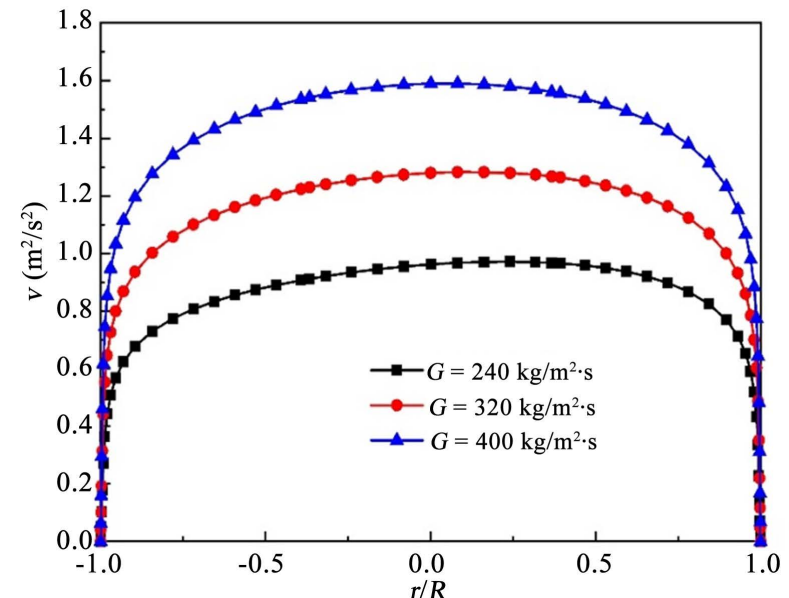

(a)

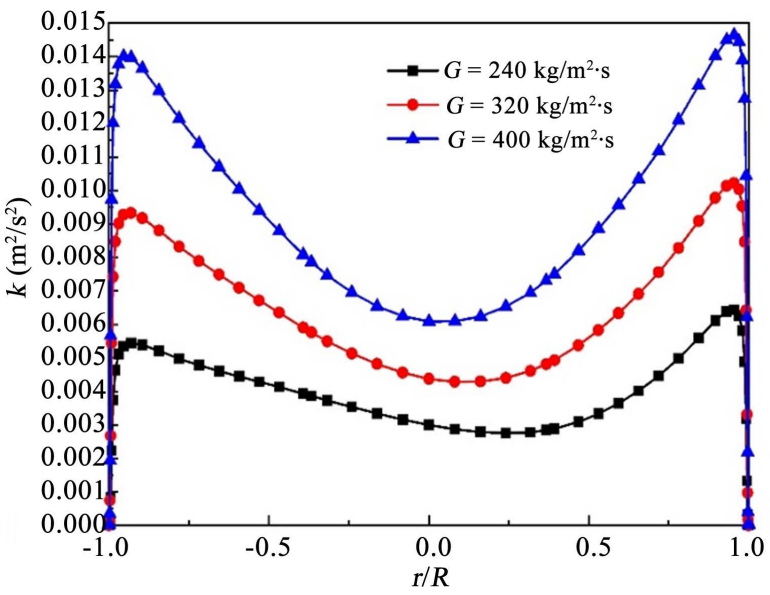

(b)

Figure 8. Radial (a) velocity and (b) turbulent kinetic energy distributions for the crosssection with the bulk temperature of $390 \mathrm{~K}$ under different mass fluxes. 


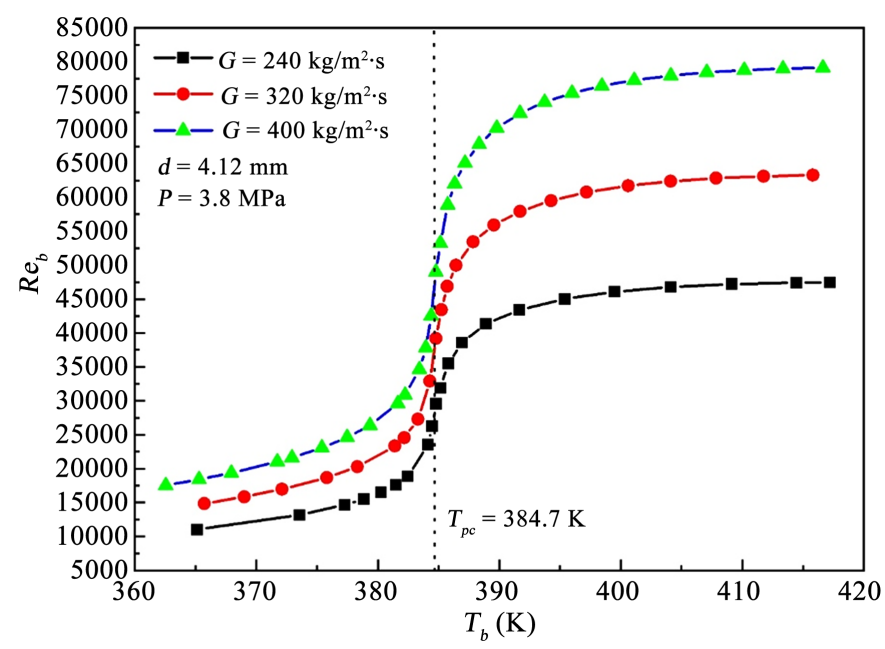

Figure 9. Reynolds numbers under different mass fluxes.

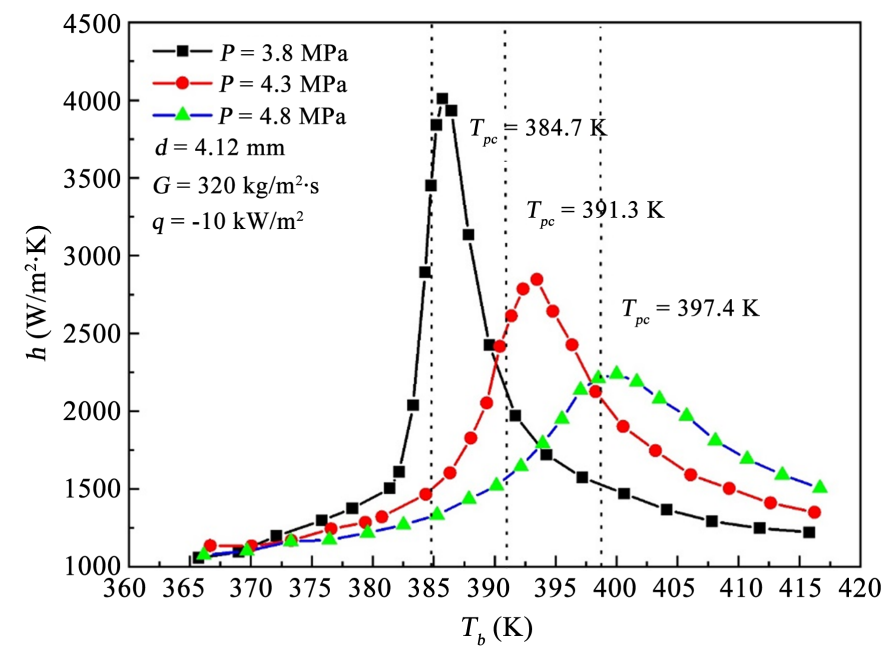

Figure 10. Effect of different pressures on $h$.

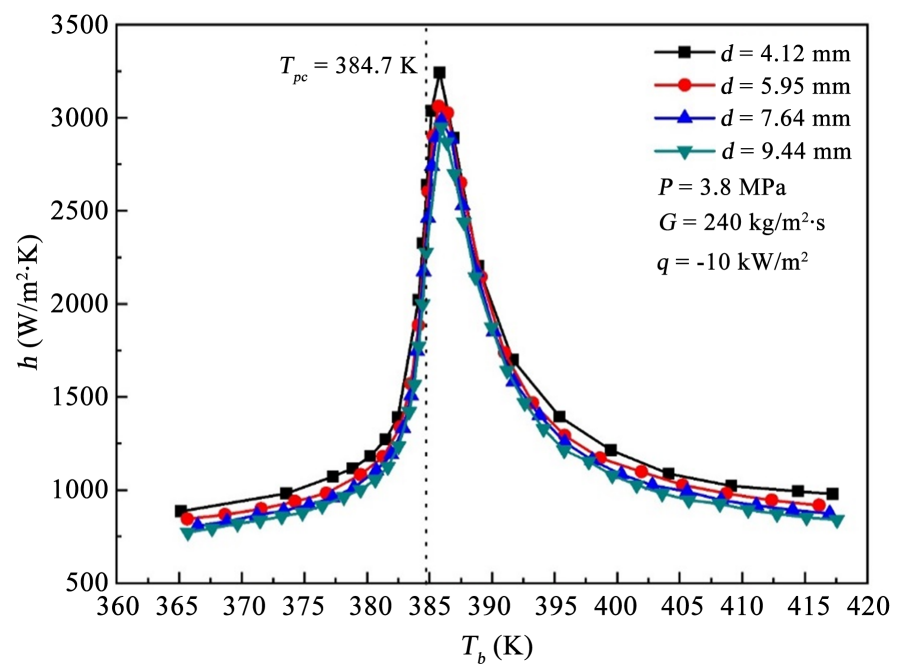

Figure 11. Influence of tube diameter on $h$. 
Table 4. Temperature contours.

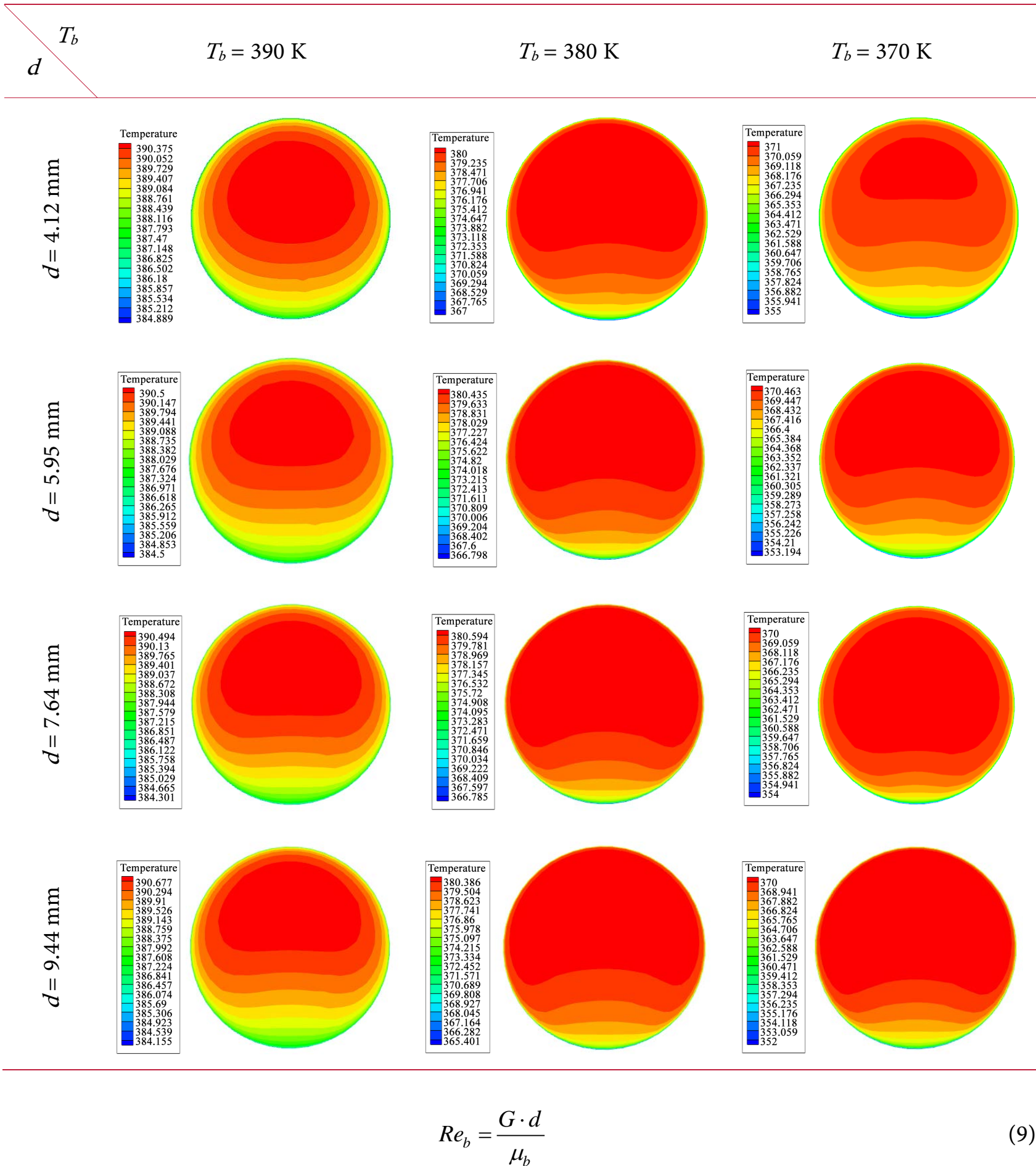

At lower diameter the dimensionless buoyancy (Richardson number) is much lower than unity (Figure 13) which results in trivial impact of buoyancy in the flow. Meanwhile, for $9.44 \mathrm{~mm}$ diameter tube at a lower temperature, the value of Richardson number is greater than 0.1. Herein, the influence of buoyancy increases the heat transfer coefficient (Figure 12). However, the increase in temperature may results in lowering the buoyancy influence (Figure 13(a)). At higher temperature, heat transfer is more influenced by $R e_{b}$ which causes an increase in $h$ values with increase in tube diameter. 


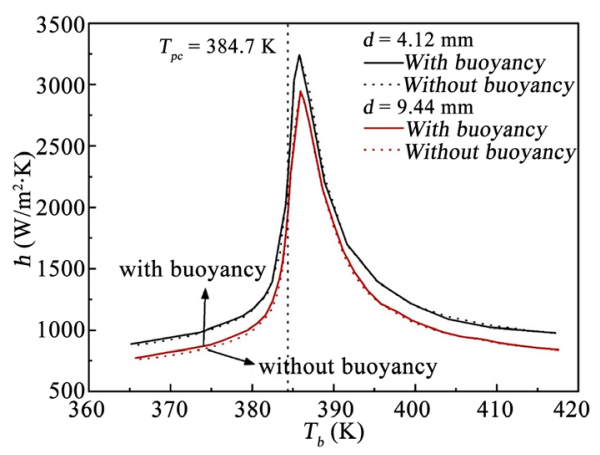

Figure 12. Influence of gravitational buoyancy on $h$.

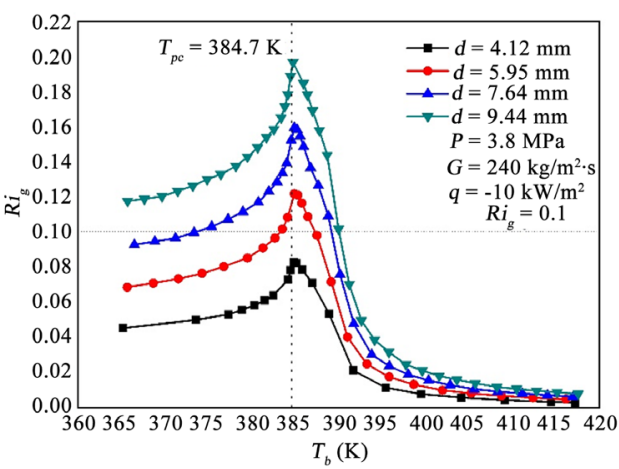

(a)

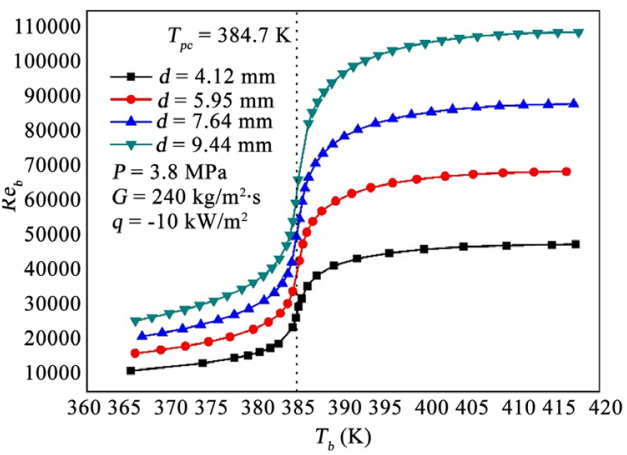

(b)

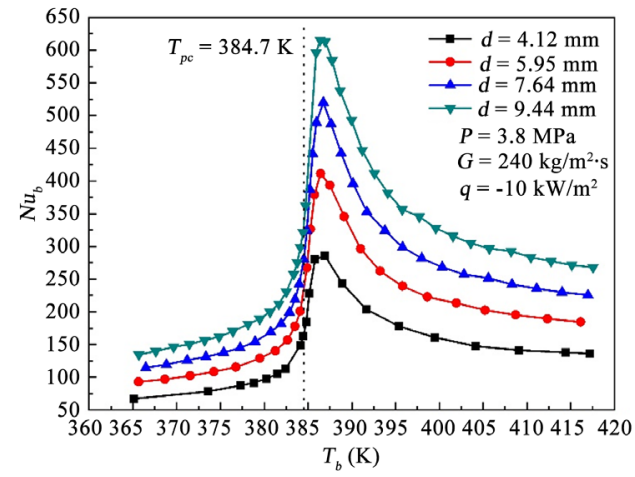

(c)

Figure 13. Comparison of the dimensionless numbers at different diameters. 


\section{CORRELATION DEVELOPMENT}

Newly developed correlations applicable to present working conditions for supercritical fluid R515A were introduced, which can accurately predict heat transfer. Meanwhile, a reasonable approach is to divide the temperature range into two regions $\left(T_{b} \geq T_{p c}\right.$ and $\left.T_{b}<T_{p c}\right)[1,2]$, which can increase prediction accuracy. The newly developed simulated correlations have prediction accuracy of $10 \%$ (Figure 14). The suggested correlation for the whole region is as follows:

$$
N u_{b}=0.084 R e_{b}^{0.703} \operatorname{Pr}_{b}^{0.179}\left(\frac{\rho_{b}}{\rho_{w}}\right)^{-0.947}\left(\frac{\bar{c}_{p}}{c_{p, w}}\right)^{-0.061}\left(\frac{G r}{R e_{b}^{2}}\right)^{0.031}
$$

A better prediction is as follows:

$$
\begin{aligned}
& T_{b}>T_{p c} \\
& N u_{b}=0.021 \operatorname{Re}_{b}^{0.806} \operatorname{Pr}_{b}^{0.338}\left(\frac{\rho_{b}}{\rho_{w}}\right)^{-0.989}\left(\frac{\bar{c}_{p}}{c_{p, w}}\right)^{-0.089}\left(\frac{G r}{R e_{b}^{2}}\right)^{-0.006} \\
& T_{b} \leq T_{p c} \\
& N u_{b}=0.024 \operatorname{Re}_{b}^{0.847} \operatorname{Pr}_{b}^{0.090}\left(\frac{\rho_{b}}{\rho_{w}}\right)^{0.650}\left(\frac{\bar{c}_{p}}{c_{p, w}}\right)^{0.411}\left(\frac{G r}{R e_{b}^{2}}\right)^{0.008}
\end{aligned}
$$

The average absolute deviation and root mean square deviation of the prediction are $3.98 \%$ and $6.02 \%$, respectively. This means that the new correlation performs very well in the heat transfer prediction of the cooling heat transfer characteristics of supercritical fluid R515A in tubes. Its application range is $3.8 \mathrm{MPa} \leq P \leq 4.8 \mathrm{MPa}, 240 \mathrm{~kg} / \mathrm{m}^{2} \cdot \mathrm{s} \leq G \leq 400 \mathrm{~kg} / \mathrm{m}^{2} \cdot \mathrm{s}, \quad-5 \mathrm{~kW} / \mathrm{m}^{2} \leq q \leq-15 \mathrm{~kW} / \mathrm{m}^{2}$ and $365 \mathrm{~K} \leq T_{b} \leq 420 \mathrm{~K}$ for horizontal tubes of $d=4.12-9.44 \mathrm{~mm}$.

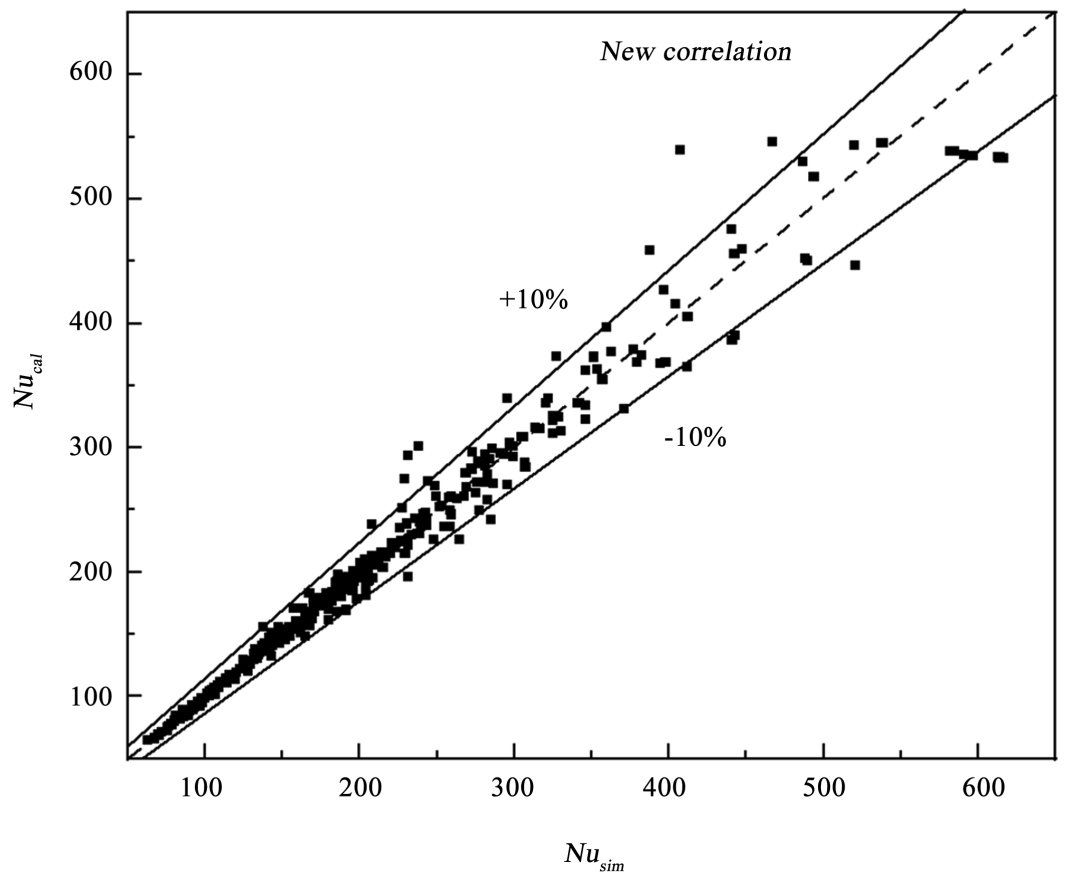

Figure 14. Simulated and calculated Nusselt numbers by dividing into two regions $\left(T_{b} \geq T_{p c}\right.$ and $\left.T_{b}<T_{p c}\right)$. 


\section{CONCLUSIONS}

The present simulations attempted to investigate supercritical fluid R515A under cooling conditions flowing through horizontal tube. Herein, investigated the influence of different pressures, heat fluxes, mass fluxes and tube diameters on the heat transfer coefficient as follows:

- The increase in mass flux from $240 \mathrm{~kg} /\left(\mathrm{m}^{2} \cdot \mathrm{s}\right)$ to $400 \mathrm{~kg} /\left(\mathrm{m}^{2} \cdot \mathrm{s}\right)$ can enhance the heat transfer owing to increase in Reynolds number. However, the increase in pressure from $3.8 \mathrm{MPa}$ to $4.8 \mathrm{MPa}$ can possibly decrease the $h$ values and can shift the peak value of heat transfer coefficient in the right region. This is possibly due to variations in thermo-physical properties, specifically the sudden change in specific heat, when the pressure is in the vicinity of pseudo critical point.

- The $9.44 \mathrm{~mm}$ diameter tube showed slightly lowered heat transfer coefficient than that of $4.12 \mathrm{~mm}$. There is a slight influence of gravitational buoyancy on heat transfer for a relatively large diameter tube $(9.44 \mathrm{~mm})$ under considered operating conditions.

- For the considered range of heat flux $\left(-5\right.$ to $\left.-15 \mathrm{~kW} / \mathrm{m}^{2}\right)$, heat transfer coefficient remained almost unchanged for lower temperature $\left(T_{b}<T_{p c}\right)$. However, $h$ values changed slightly at higher temperature $\left(T_{b} \geq T_{p c}\right)$.

- Moreover, heat transfer correlations were suggested to accurately predict Nusselt number within $10 \%$. The average absolute deviation and root mean square deviation of the prediction are $3.98 \%$ and $6.02 \%$, respectively. The experimental investigations would be crucial that can further validate and improve the accuracy of prediction for heat transfer coefficient.

Owing to environmental issues, the present simulations suggest that R515A is a considerable replacement of R134a. Further investigations are required to thoroughly explore the heat transfer characteristics of potential alternatives in cooling and heating conditions.

\section{ACKNOWLEDGEMENTS}

This work is supported by the National Natural Science Foundation of China (Grant No. 51576187).

\section{CONFLICTS OF INTEREST}

The authors declare no conflicts of interest regarding the publication of this paper.

\section{REFERENCES}

1. Jiang, Y.-R., Hu, P. and Ibrahim, A. (2020) Experimental and Numerical Investigation on Heat Transfer Characteristics of Supercritical R1234ze (E) Cooled in Horizontal Tubes. International Journal of Heat and Fluid Flow, 85, Article ID: 108650. https://doi.org/10.1016/j.ijheatfluidflow.2020.108650

2. Zhang, G.-W., Hu, P., Chen, L.-X. and Liu, M.-H. (2018) Experimental and Simulation Investigation on Heat Transfer Characteristics of In-Tube Supercritical $\mathrm{CO}_{2}$ Cooling Flow. Applied Thermal Engineering, 143, 11011113. https://doi.org/10.1016/j.applthermaleng.2018.07.108

3. Ibrahim, A., Peng, H., Riaz, A., Basit, M.A., Rashid, U. and Basit, A. (2021) Molten Salts in the Light of Corrosion Mitigation Strategies and Embedded with Nanoparticles to Enhance the Thermophysical Properties for CSP Plants. Solar Energy Materials and Solar Cells, 219, Article ID: 110768. https://doi.org/10.1016/j.solmat.2020.110768

4. Tian, R., Wang, D., Zhang, Y., Ma, Y., Li, H. and Shi, L. (2019) Experimental Study of the Heat Transfer Characteristics of Supercritical Pressure R134a in a Horizontal Tube. Experimental Thermal and Fluid Science, 100, 49-61. https://doi.org/10.1016/j.expthermflusci.2018.08.027

5. Mishra, S., Nayak, M. and Misra, A. (2020) Thermal Conductivity of Nanofluids-A Comprehensive Review. International Journal of Thermofluid Science and Technology, 7, 1-51. https://doi.org/10.36963/IJTST.2020070301

6. Zhou, Y., Zhang, L., Bu, S., Sun, C., Xu, W., Xiao, Y. and Liu, L. (2020) Study on Heat Transfer Characteristics 
of the Whole Plate Fin Tube Cooler. International Journal of Thermofluid Science and Technology, 7, Article ID: 070204.

7. Islam, T., Parveen, N. and Asad, M. (2020) Hydromagnetic Natural Convection Heat Transfer of Copper-Water Nanofluid within a Right-Angled Triangular Cavity. International Journal of Thermofluid Science and Technology, 7, 1-18. https://doi.org/10.36963/IJTST.2020070304

8. Marques, S.P. and Campo, A. (2019) Finite Strip Method Applied to Steady Heat Conduction and Thermal Radiation in a Planar Slab: Absorbing-Emitting Gray Material and Parallel Diffuse Surfaces. International Journal of Thermofluid Science and Technology, 6, Article ID: 19060102. https://doi.org/10.36963/IJTST.19060102

9. Cui, Y., Wang, H., Wang, Y. (2019) Experimental and Numerical Studies on Convective Heat Transfer of Supercritical R-134a in a Horizontal Tube. International Journal of Heat and Mass Transfer, 136, 34-45. https://doi.org/10.1016/j.ijheatmasstransfer.2019.02.083

10. Wang, D., Tian, R., Zhang, Y., Li, L., Ma, Y., Shi, L. and Li, H. (2019) Heat Transfer Investigation of Supercritical R134a for Trans-Critical Organic Rankine Cycle System. Energy, 169, 542-557. https://doi.org/10.1016/j.energy.2018.12.034

11. Ye, K., Zhang, Y., Yang, L., Zhao, Y., Li, N. and Xie, C. (2019) Modeling Convective Heat Transfer of Supercritical Carbon Dioxide Using an Artificial Neural Network. Applied Thermal Engineering, 150, 686-695. https://doi.org/10.1016/j.applthermaleng.2018.11.031

12. Ehsan, M.M., Guan, Z. and Klimenko, A. (2018) A Comprehensive Review on Heat Transfer and Pressure Drop Characteristics and Correlations with Supercritical $\mathrm{CO}_{2}$ under Heating and Cooling Applications. Renewable and Sustainable Energy Reviews, 92, 658-675. https://doi.org/10.1016/j.rser.2018.04.106

13. Huang, D., Wu, Z., Sunden, B. and Li, W. (2016) A Brief Review on Convection Heat Transfer of Fluids at Supercritical Pressures in Tubes and the Recent Progress. Applied Energy, 162, 494-505.

https://doi.org/10.1016/j.apenergy.2015.10.080

14. Wang, H., Leung, L.K., Wang, W. and Bi, Q. (2018) A Review on Recent Heat Transfer Studies to Supercritical Pressure Water in Channels. Applied Thermal Engineering, 142, 573-596.

https://doi.org/10.1016/j.applthermaleng.2018.07.007

15. Rahman, M.M., Dongxu J., Beni, M.S., Hei, H.C., He, W. and Zhao, J. (2016) Supercritical Water Heat Transfer for Nuclear Reactor Applications: A Review. Annals of Nuclear Energy, 97, 53-65.

https://doi.org/10.1016/j.anucene.2016.06.022

16. Zhang, S., Xu, X., Liu, C. and Dang, C. (2020) A Review on Application and Heat Transfer Enhancement of Supercritical $\mathrm{CO}_{2}$ in Low-Grade Heat Conversion. Applied Energy, 269, Article ID: 114962.

https://doi.org/10.1016/j.apenergy.2020.114962

17. Knez, Ž., Markočič, E., Leitgeb, M., Primožič, M., Hrnčič, M.K. and Škerget, M. (2014) Industrial Applications of Supercritical Fluids: A Review. Energy, 77, 235-243. https://doi.org/10.1016/j.energy.2014.07.044

18. Huang, D. and Li, W. (2018) A Brief Review on the Buoyancy Criteria for Supercritical Fluids. Applied Thermal Engineering, 131, 977-987. https://doi.org/10.1016/j.applthermaleng.2017.12.042

19. Dang, C. and Hihara, E. (2004) In-Tube Cooling Heat Transfer of Supercritical Carbon Dioxide. Part 1. Experimental Measurement. International Journal of Refrigeration, 27, 736-747.

https://doi.org/10.1016/j.ijrefrig.2004.04.018

20. Dang, C. and Hihara, E. (2004) In-Tube Cooling Heat Transfer of Supercritical Carbon Dioxide. Part 2. Comparison of Numerical Calculation with Different Turbulence Models. International Journal of Refrigeration, 27, 748-760. https://doi.org/10.1016/j.ijrefrig.2004.04.017

21. Wang, J., Guan, Z., Gurgenci, H., Hooman, K., Veeraragavan, A. and Kang, X. (2018) Computational Investiga- 
tions of Heat Transfer to Supercritical $\mathrm{CO}_{2}$ in a Large Horizontal Tube. Energy Conversion and Management, 157, 536-548. https://doi.org/10.1016/j.enconman.2017.12.046

22. Zahlan, H., Groeneveld, D. and Tavoularis, S. (2015) Measurements of Convective Heat Transfer to Vertical Upward Flows of $\mathrm{CO}_{2}$ in Circular Tubes at Near-Critical and Supercritical Pressures. Nuclear Engineering and Design, 289, 92-107. https://doi.org/10.1016/j.nucengdes.2015.04.013

23. Zhao, C.-R. and Jiang, P.-X. (2011) Experimental Study of In-Tube Cooling Heat Transfer and Pressure Drop Characteristics of R134a at Supercritical Pressures. Experimental Thermal and Fluid Science, 35, 1293-1303. https://doi.org/10.1016/j.expthermflusci.2011.04.017

24. Wang, D., Tian, R., Zhang, Y., Li, L. and Shi, L. (2019) Experimental Comparison of the Heat Transfer of Supercritical R134a in a Micro-Fin Tube and a Smooth Tube. International Journal of Heat and Mass Transfer, 129, 1194-1205. https://doi.org/10.1016/j.ijheatmasstransfer.2018.10.052

25. Wang, D., Tian, R., Li, L., Dai, X. and Shi, L. (2020) Heat Transfer of R134a in a Horizontal Internally Ribbed Tube and in a Smooth Tube under Super Critical Pressure. Applied Thermal Engineering, 173, Article ID: 115208. https://doi.org/10.1016/j.applthermaleng.2020.115208

26. Kang, K.-H. and Chang, S.-H. (2009) Experimental Study on the Heat Transfer Characteristics during the Pressure Transients under Supercritical Pressures. International Journal of Heat and Mass Transfer, 52, 4946-4955. https://doi.org/10.1016/j.ijheatmasstransfer.2009.06.005

27. Cui, Y.-L. and Wang, H.-X. (2018) Experimental Study on Convection Heat Transfer of R134a at Supercritical Pressures in a Vertical Tube for Upward and Downward Flows. Applied Thermal Engineering, 129, 1414-1425. https://doi.org/10.1016/j.applthermaleng.2017.10.120

28. He, J., Dang, C. and Hihara, E. (2018) Experimental Investigation of Heat Transfer to Supercritical R245fa Flowing Vertically Upward in a Circular Tube. International Journal of Heat and Mass Transfer, 127, 286-295. https://doi.org/10.1016/j.ijheatmasstransfer.2018.06.126

29. He, J., Dang, C. and Hihara, E. (2018) Supercritical Heat Transfer Characteristics of R1233zd (E) in Vertically Upward Flow. International Journal of Heat and Mass Transfer, 127, 497-505. https://doi.org/10.1016/j.ijheatmasstransfer.2018.07.078

30. Jiang, P.-X., Zhao, C.-R. and Liu, B. (2012) Flow and Heat Transfer Characteristics of r22 and Ethanol at Supercritical Pressures. The Journal of Supercritical Fluids, 70, 75-89. https://doi.org/10.1016/j.supflu.2012.06.011

31. Xiong, Z., Gu, H., Zhang, S. and Chen, J. (2017) Effect of Intermittent Heating on the Heat Transfer Performance of Supercritical R134a Flowing in a Pipe. Experimental Thermal and Fluid Science, 88, 434-443. https://doi.org/10.1016/j.expthermflusci.2017.06.014

32. Liu, X., Xu, X., Liu, C., Ye, J., Li, H., Bai, W. and Dang, C. (2017) Numerical Study of the Effect of Buoyancy Force and Centrifugal Force on Heat Transfer Characteristics of Supercritical $\mathrm{CO}_{2}$ in Helically Coiled Tube at Various Inclination Angles. Applied Thermal Engineering, 116, 500-515.

https://doi.org/10.1016/j.applthermaleng.2017.01.103

33. Zhang, S., Xu, X., Liu, C., Liu, X., Ru, Z. and Dang, C. (2020) Experimental and Numerical Comparison of the Heat Transfer Behaviors and Buoyancy Effects of Supercritical $\mathrm{CO}_{2}$ in Various Heating Tubes. International Journal of Heat and Mass Transfer, 149, Article ID: 119074. https://doi.org/10.1016/j.ijheatmasstransfer.2019.119074

34. Wang, K.-Z., Xu, X.-X., Liu, C., Bai, W.-J. and Dang, C.-B. (2017) Experimental and Numerical Investigation on Heat Transfer Characteristics of Supercritical $\mathrm{CO}_{2}$ in the Cooled Helically Coiled Tube. International Journal of Heat and Mass Transfer, 108, 1645-1655. https://doi.org/10.1016/j.ijheatmasstransfer.2017.01.004

35. Xiang, M., Guo, J., Huai, X. and Cui, X. (2017) Thermal Analysis of Supercritical Pressure $\mathrm{CO}_{2}$ in Horizontal Tubes under Cooling Condition. The Journal of Supercritical Fluids, 130, 389-398. 
https://doi.org/10.1016/j.supflu.2017.04.009

36. Wang, K., Xu, X., Wu, Y., Liu, C. and Dang, C. (2015) Numerical Investigation on Heat Transfer of Supercritical $\mathrm{CO}_{2}$ in Heated Helically Coiled Tubes. The Journal of Supercritical Fluids, 99, 112-120.

https://doi.org/10.1016/j.supflu.2015.02.001

37. Palko, D. and Anglart, H. (2008) Theoretical and Numerical Study of Heat Transfer Deterioration in High Performance Light Water Reactor. Science and Technology of Nuclear Installations, 2008, Article ID: 405072. https://doi.org/10.1155/2008/405072

38. Liu, L., Xiao, Z., Yan, X., Zeng, X. and Huang, Y. (2013) Heat Transfer Deterioration to Supercritical Water in Circular Tube and Annular Channel. Nuclear Engineering and Design, 255, 97-104. https://doi.org/10.1016/j.nucengdes.2012.09.025

39. Wen, Q. and Gu, H. (2011) Numerical Investigation of Acceleration Effect on Heat Transfer Deterioration Phenomenon in Supercritical Water. Progress in Nuclear Energy, 53, 480-486.

https://doi.org/10.1016/j.pnucene.2011.02.012

40. Podila, K. and Rao, Y. (2015) CFD Analysis of Flow and Heat Transfer in Canadian Supercritical Water Reactor Bundle. Annals of Nuclear Energy, 75, 1-10. https://doi.org/10.1016/j.anucene.2014.07.039

41. Zhao, H., Li, X. and Wu, X. (2017) Numerical Investigation of Supercritical Water Turbulent Flow and Heat Transfer Characteristics in Vertical Helical Tubes. The Journal of Supercritical Fluids, 127, 48-61. https://doi.org/10.1016/j.supflu.2017.03.016

42. Jaromin, M. and Anglart, H. (2013) A Numerical Study of Heat Transfer to Supercritical Water Flowing Upward in Vertical Tubes under Normal and Deteriorated Conditions. Nuclear Engineering and Design, 264, 61-70. https://doi.org/10.1016/j.nucengdes.2012.10.028

43. Han, C.-L., Zhang, Y.-N., Yu, H., Lu, Y.-P. and Jiao, B. (2018) Numerical Analysis on Non-Uniform Flow and Heat Transfer of Supercritical Cryogenic Methane in a Heated Horizontal Circular Tube. The Journal of Supercritical Fluids, 138, 82-91. https://doi.org/10.1016/j.supflu.2018.04.007

44. Zhang, P., Huang, Y., Shen, B. and Wang, R. (2011) Flow and Heat Transfer Characteristics of Supercritical Nitrogen in a Vertical Mini-Tube. International Journal of Thermal Sciences, 50, 287-295.

https://doi.org/10.1016/j.ijthermalsci.2010.06.014

45. Xiao, Y., Pan, J. and Gu, H. (2018) Numerical Investigation of Spacer Effects on Heat Transfer of Supercritical Fluid Flow in an Annular Channel. International Journal of Heat and Mass Transfer, 121, 343-353. https://doi.org/10.1016/j.ijheatmasstransfer.2018.01.030

46. Yang, Z., Cheng, X., Zheng, X. and Chen, H. (2019) Numerical Investigation on Heat Transfer of the Supercritical Fluid Upward in Vertical Tube with Constant Wall Temperature. International Journal of Heat and Mass Transfer, 128, 875-884. https://doi.org/10.1016/j.ijheatmasstransfer.2018.09.049

47. Kedzierski, M. and Lin, L. (2020) Pool Boiling of R515A, R1234ze (E), and R1233zd (E) on a Reentrant Cavity Surface. International Journal of Heat and Mass Transfer, 161, Article ID: 120252. https://doi.org/10.1016/j.ijheatmasstransfer.2020.120252

48. Petersen, M., Pottker, G., Sethi, A. and Yana Motta, S.F. (2018) Refrigerants with Low Environmental Impact for Commercial Refrigeration Systems.

49. He, Y.-J., He, L.-F., Zheng, S.-P. and Chen, G.-M. (2020) Measurements of Isobaric Heat Capacity of R143a and R227ea at Liquid Phase by Quasi-Steady Scanning. Thermochimica Acta, 683, Article ID: 178464. https://doi.org/10.1016/j.tca.2019.178464

50. Saengsikhiao, P., Taweekun, J., Maliwan, K., Saeung, S. and Theppaya, T. (2020) Investigation and Analysis of R463A as an Alternative Refrigerant to R404A with Lower Global Warming Potential. Energies, 13, 1514. https://doi.org/10.3390/en13061514 
51. Ibrahim, A., Hu, P., Jiang, Y.R., Riaz, A., Saleem, F., Dong, Y.F., Jia, L. and Zhao, P.P. (2021) Numerical Investigations on Supercritical Heat Transfer Characteristics of Environmental Friendly Refrigerants. International Journal of Clean Coal and Energy, 10, 21-40. https://doi.org/10.4236/ijcce.2021.102002

\section{NOMENCLATURE}

$\begin{array}{ll}A & \text { cross-sectional area }\left(\mathrm{mm}^{2}\right) \\ C_{p} & \text { specific heat }[\mathrm{J} /(\mathrm{kg} \cdot \mathrm{K})] \\ \bar{c}_{p} & \text { average specific heat }[\mathrm{J} /(\mathrm{kg} \cdot \mathrm{K})] \\ d & \text { diameter }(\mathrm{mm}) \\ G & \text { mass flux }\left[\mathrm{kg} /\left(\mathrm{m}^{2} \cdot \mathrm{s}\right)\right] \\ G r & \text { Grashof number } \\ h & \text { heat transfer coefficient }\left[\mathrm{W} /\left(\mathrm{m}^{2} \cdot \mathrm{K}\right)\right] \\ i & \text { enthalpy }(\mathrm{J} / \mathrm{kg}) \\ k & \text { turbulent kinetic energy }\left(\mathrm{m}^{2} / \mathrm{s}^{2}\right) \\ \dot{m} & \text { mass flow rate }(\mathrm{kg} / \mathrm{s}) \\ N u & \text { Nusselt number } \\ P & \text { pressure }(\mathrm{MPa}) \\ P r & \text { Prandtl number } \\ q & \text { heat flux }\left(\mathrm{kW} / \mathrm{m}^{2}\right) \\ Q & \text { heat exchange amount }(\mathrm{kW}) \\ r & \text { radial coordinate }(\mathrm{mm}) \\ R & \text { tube radius }(\mathrm{mm}) \\ R e & \text { Reynolds number } \\ R i & \text { Richardson number } \\ T & \text { temperature }(\mathrm{K}) \\ u & \text { fluid velocity }(\mathrm{m} / \mathrm{s}) \\ V & \text { velocity }(\mathrm{m} / \mathrm{s}) \\ G r e e k & s y m b o l s \\ \lambda & \text { Thermal conductivity }[\mathrm{W} /(\mathrm{m} \cdot \mathrm{K})] \\ \mu & \text { viscosity }(\mathrm{g} / \mathrm{m} \cdot \mathrm{s}) \\ \rho & \text { density }\left(\mathrm{kg} / \mathrm{m}^{3}\right) \\ A b b r e v i a t i o n s / A c r o n y m s \\ \mathrm{GWP} & \text { Global Warming Potential } \\ \mathrm{LB} & \text { Lattice-Boltzmann } \\ \mathrm{ODP} & \text { Ozone Depletion Potential } \\ \mathrm{SST} & \text { Shear Stress Transport } \\ & \end{array}$

